\title{
Cinema and Violence against Women: Contribution to the Formation of Clinical Psychologist
}

\author{
Tales Vilela Santeiro ${ }^{1}$ \\ Universidade Federal do Triângulo Mineiro, Uberaba, MG, Brazil \\ Joice Veridiane Schumacher \\ Tatiana Machiavelli Carmo Souza \\ Universidade Federal de Goiás, Jataí, GO, Brazil
}

\begin{abstract}
The research objectives were analyze business / fictional films about Violence Against Woman (VAW). The selection of films was systematic and carried out in specialized sites on the subject (AdoroCinema, Cinepop etc.), across terms like "violence" and "woman" $(N=19)$. The analysis assumed three steps: observation of motion pictures; data entry observed in spreadsheets; simple frequency ratio concerning VAW scenarios with theoretical aspects pointed out by the literature (quantitative and qualitative approach). The aggressor were strangers $(n=11,39 \%)$, husbands $(n=9,33 \%)$, boyfriends $(\mathrm{n}=4,14 \%)$ and others $(n=4,14 \%)$. There were performances of the following types of violence: psychological $(n$ $=19,27 \%)$, physical $(n=18,25 \%)$, sexual $(n=16,22 \%)$, moral $(n=12,16 \%)$ and patrimonial $(n=7$, $10 \%)$. The filmic representations showed general signs of psychological traumatization in characters $(n$ $=17,37 \%$ ). The studied films are illustrative of the reality of women in situations of violence; as such can be converted to amplifying teaching tool for discussion and reflection on gender issues and on health promotion in the context of VAW.
\end{abstract}

Keywords: Clinical psychology, gender violence, films, intrafamily violence.

\section{Cinema e Violência Contra a Mulher: Contribuições à Formação do Psicólogo Clínico}

\section{Resumo}

Os objetivos da pesquisa foram analisar filmes comerciais/ficcionais sobre Violência Contra a Mulher (VCM), buscando caracterizar encenações desse fenômeno. A seleção dos filmes foi sistemática e realizada em sites especializados no assunto (AdoroCinema, Cinepop etc.), cruzando termos como "violência" e "mulher" $(N=19)$. A análise pressupôs três passos: observação das películas; lançamento de dados observados em planilhas; relação de frequências simples de encenações sobre VCM com aspectos teóricos apontados pela literatura especializada (enfoque quanti-qualitativo). Os agressores eram estranhos $(n=11,39 \%)$, maridos $(n=9,33 \%)$, namorados $(n=4,14 \%)$ e outros $(n=4,14 \%)$. Houve encenações de violência psicológica $(n=19,27 \%)$, física $(n=18,25 \%)$, sexual $(n=16,22 \%)$, moral ( $n=12,16 \%)$ e patrimonial $(n=7,10 \%)$. As representações fílmicas focaram indícios gerais de traumatização psíquica nas personagens $(n=17,37 \%)$. Os filmes estudados são ilustrativos da realidade

Mailing address: Universidade Federal do Triângulo Mineiro, Departamento de Psicologia. Avenida Getúlio Guaritá, 159, $3^{\circ}$ andar. Nossa Senhora da Abadia. CEP 38025-440, Uberaba, MG, Brasil. E-mail: talesanteiro@ hotmail.com and tatimachiavelli@yahoo.com.br

Financing: Programa Institucional de Bolsas da Universidade Federal de Goiás (PIBIC-UFG/Conselho Nacional de Desenvolvimento Científico e Tecnológico [CNPQ]). 
das mulheres em contextos de violência; enquanto tais, podem ser convertidos em ferramenta didática ampliadora de debates e reflexões sobre questões de gênero e sobre promoção de saúde em contexto de VCM.

Palavras-chave: Psicologia clínica, violência de gênero, filmes, violência intrafamiliar.

\section{El Cine y la Violencia Contra las Mujeres: Contribución a la Formación de Psicólogo Clínico}

\section{Resumen}

Los objetivos de la investigación fueron analizar las películas de ficción sobre Violencia Contra las Mujeres (VCM), buscando caracterizar escenarios de este fenómeno. La selección de las películas era sistemática y lleva a cabo en los sitios especializados en la materia, a través de términos como "violência" y "mujer" $(N=19)$. El análisis supone tres etapas: la observación de las películas; la entrada de datos observados en las hojas de cálculo; relación de frecuencias simples de las representaciones del VCM con aspectos teóricos señalados por la literatura (enfoque cuantitativo y cualitativo). Los atacantes eran desconocidos (39\%), esposos (33\%), novios (14\%) y otros (14\%). Había un escenario psicológico (27\%), física (25\%), el sexo (22\%), la moral (16\%) y el resto $(10 \%)$. Las representaciones fílmicas mostraron signos generales de traumas psicológicos en caracteres (37\%). Las películas estudiadas son ilustrativos de la realidad de las mujeres en situación de violencia; como tal, se puede convertir en la amplificación de herramienta de enseñanza para el debate y la reflexión sobre temas de género y en la promoción de la salud en el contexto de VCM.

Palabras clave: Psicología clínica, violencia de género, películas, violencia intrafamiliar.

Cinema, also known as the Seventh Art, is one of the great advents of the $19^{\text {th }}$ century, created by the Lumière brothers (Bernardet, 2006). In the course of its history, its language moved from merely showing facts to storytelling and, in doing so, became highly sophisticated, based on semiotic, narrative, intertextual and ideological elements (Edgard-Hunt, Marland, \& Rawle, 2013).

Clinical Psychology, in turn, emerged at the same time as the Cinema; it is rooted in the medical model, in which the professional's function is to observe and understand, followed by an intervention, that is, remedying, treating, curing. At first, this was a healthcare practice, remaining distant from social issues for a long time (Moreira, Romagnoli, \& Neves, 2007), being these issues problems that affect society in general. Like hunger, poverty, withdrawal of human rights, violence and particularly violence against women (VAW), focused on in this study, it became the subject of commercial/fictional movies.
In psychotherapeutic education - one professional trajectory in Clinical Psychology three basic references exist for the development of a good professional, which are: reading about the theory and technique that will guide one's practice, personal analysis and supervision, in which technical aspects of the interventions can be enhanced and the clinical discussion of care cases can be further elaborated (Portella, Cortez, \& Carpigiani, 2011).

In that context, the Seventh Art can contribute as a tool in the professional qualification of clinical psychologists. It can be integrated into the theoretical knowledge, triggering discussions, arousing reflections and elaborations on the experiences the future psychologists will face in their profession (Santeiro, 2013).

In view of the phenomenon VAW, the Cinema can serve as an illustrative instrument for psychologists in training, about the reality they may be confronted with in clinical practice. As it is mediated and dialogued, the movie language 
... would be capable of developing clinical skills, as it would function like the other the psychologist will work with. Another person who arrives and is marked by histories, which were written and perceived based on the internal and external, subjective and objective realities. (Santeiro, 2013, p. 195)

In that sense, the movie language reflects and at the same time construct social practices and meanings.

\section{Violence against Women}

The phenomenon of VAW has increasingly gained attention in the media, including the Cinema (Pinheiro, 2012; Strasburger, Wilson, \& Jordan, 2011). This is a relevant theme for discussion in education processes of clinical psychologists, in view of its repercussions and social, cultural and historical impact.

Recently, VAW has been considered a multifaceted and multicausal public health theme. Therefore, it has required the creation of specific laws, programs and public policies (e.g. Decreto-lei $\left.N .{ }^{\circ} 11.340,2006\right)$ and the consolidation of the Specialized Women's Precincts (DEAM) and Shelter-Houses - protected housing for women at risk.

It should be observed that, in context in which VAW happens, the psychotherapist and clinical psychologist may serve as important elements in the process of breaking and coping with the cycle of violence (Conselho Federal de Psicologia, 2011). These professionals can offer specialized and confidential listening, thus allowing women in situations of violence to share their experience that made them feel pain. And through this listening, they allow them to recover their condition as subjects, their selfesteem, their desires that were suspended while they were victims of violence (Pimentel, 2011).

'Violence against women' is a term that should be used in the plural form, as it joins multiple expressions and forms of violence, such as physical, sexual, verbal, (intra)family, domestic, traffic aggressions, among other possibilities. It is perpetrated by a wide range of sobjects in a wide range of contexts (acquaintances, (former) unfamiliar partners, public and private insti- tutions, State). According to article $5^{\text {th }}$ of Law 11.340 (2006), this is “. . . any action or omission based on gender that causes death, injury, physical, sexual or psychological suffering and moral or equity damage".

VAW does not come down to the use of physical force, but to any threat to use it. It is linked to the power a person exerts on the other for that other person to do his/her will, whether by fear or force. It is not only directed at certain social groups of women, but “. . . represents one of the most aggressive forms of patriarchy (expressed in machismo), which is supported and consented . . . by the ideological appliances that reproduce the predominant patriarchal logic" (Mesquita, 2010, p. 8).

In its article $7^{\text {th }}$, Law 11.340 classifies five types of domestic and family violence against women (Decreto-lei N. ${ }^{\circ} 11.340,2006$ ):

1. Physical, considered as any conduct that impairs physical integrity and health;

2. Psychological which comprises any conduct that causes some emotional problem, reduced self-esteem, impairs development, limits the right to come and go, among others;

3. Equity, defined as any behavior that means the retention, subtraction or ownership of any object or goods people may possess;

4. Sexual, characterized by any conduct that may oblige people to witness or take part in a sexual relationship beyond their will or which somehow impedes them from exercising their sexual freedom; and, finally,

5. Moral, characterized by any behavior that takes the form of libel, insult or defamation. Coping with VAW cannot be restricted to its combat. It should also comprise the dimensions of prevention, care and guarantee of women's rights (Política Nacional de Enfrentamento à Violência contra as Mulheres, 2011). The clinical psychologist's work can operate in all of these dimensions (Hanada, D'Oliveira, \& Schraiber, 2011). In that context, women's care services should be fundamentally focused in the broadest and most comprehensive sense, involving other mental health and human and applied social science professionals. That demands an 
intersectoral and multidimensional focus from the State and the professionals, whether psychologists or not, which is capable of provoking cultural, educative and social changes (Politica Nacional de Enfrentamento à Violência contra as Mulheres, 2011).

According to Waiselfisz (2015), 85.9 thousand girls and women in situations of violence committed by a family member or intimate partner were attended in the Brazilian Unified Health System in 2014 only. In view of these data, studies are important to grant visibility to the VAW phenomenon. Besides these issues, women in situations of violence will possibly figure among the patients the psychologist will meet in clinical practice.

\section{Considerations on Violence and VAW from a Psychoanalytical Perspective}

Based on psychoanalytic theory, one might say the term violence is applied in a wide range of contexts, making it a problem to understand it. The human being is tempted at all times to satisfy the need aggressive impulses entail; satisfying them at the cost of fellow human beings, exploring their work, taking hold of their possessions without their consent using them sexually without their permission, causing them suffering, assaulting them, making them feel pain, torturing and killing them (Vieira, 2013).

Violence is an attack on the violated subject and tends to entail disastrous effects on their subjectivity (Fiorini, 2008). Therefore, the concept of mental trauma should be discussed to clarify the phenomenon of VAW. Freud (1920/1996) describes trauma as pain that cannot be represented mentally and this lack of representation entails great impact in the person's subjectivation process. An experience will be considered traumatic when the anguish and pain reach an unbearable point, which grant the subject a feeling that their I has been ruptured.

Under the effect of the trauma, the mechanism of compulsion to repeat emerges, in which the disturbing, afflictive event returns repetitively, but elaborated by the psyche. This apparatus corresponds to certain people's action to repeat past events, afflictive situations in their lives, without acknowledging their own participation in bringing about these incidents or in relating the current situations with past experiences (Paim, 2010).

In the repetition compulsion phenomenon, the person is obliged to repeat the repressed material as if it were a new experience, instead of reminding it as something that belongs to the past (Freud, 1920/1996). What is repeated are mostly childhood experiences that caused suffering, mainly those related to losses inherent in life. These experiences "return" implied in different ways (Barbosa, 2010), as if the subject remained in a state of "search" to elaborate what could not be emotionally understood regarding the experience of the traumatic situation itself.

The traumas experienced in childhood will find a place in adult life to manifest themselves; people who have been through situations of mistreatment in the past can relive them in the present without being aware of this repetition (Lima \& Werlang, 2011). Thus, women whose own or whose family's histories contain cases of violence can unconsciously relive these episodes in adult life. In these situations, the women reissue childhood experiences by way of known difficulties, repeating the problem.

In view of this introduction, in this study, the objective was to survey commercial movies on the theme VAW and to verify whether the cases of VAW displayed are related to aspects focused on in the specialized literature.

\section{Method}

The search for movie titles was undertaken on specialized cinema websites, considering the results ranked first on the search engine Google: AdoroCinema, Cine Pop, Omelete, e-pipoca, Cinema 10 and Netflix. On each of these websites, the following words were considered in the search for movies: "violence", "abuse", "girl", "mother" and "woman".

The following criteria were adopted to include the titles in the sample: (a) issued between 2005 and 2014; and (b) language or subtitles in Portuguese; (c) availability to watch on DVD, from video stores or from the websites on which 
the search was undertaken; and (d) picturing of VAW through images and/or dialogues, as the core (performances by leading characters, or long scenes in relation to the total movie length, i.e. not sporadic) or secondary theme (performances by supporting actors, or short scenes in relation to the total movie length, i.e. sporadic).

The first search for movies resulted in 20 titles, one of which did not comply with the preset criteria and was excluded from the sample, as it was a documentary: Canto de cicatriz. The movie search mechanisms had included the documentary because it also discusses VAW. Among the 19 movies selected, two were randomly chosen for pilot studies (An unfinished life and Provoked).

Based on the pilot studies and central aspects of VAW appointed in the specialized literature, a form was developed to register observations. To complete the form, the movies were watched scene by scene, paying particular attention to the following matters, which were observed systemically in each of the movies: (a) What is the genre (drama, comedy, horror, thriller etc.) and the country of origin of the movie?; (b) Are situations of VAW pictured on the forefront or in the background, in the arguments of the movies?; (c) In what contexts does VAW take place (institutional [family, school, religious etc.] and non-institutional [streets, squares, parks etc.])?; (d) What is the profile of the women in situations of violence and the aggressors (age, degree of proximity, job or not, children or not, marital status)?; (e) What type(s) of VAW (sexual, physical, psychological, equity and moral) is(are) pictured?; (f) What implications did the act of violence entail for the woman? Considering that one of the implications pictured may be mental trauma, did the victim present any symptom? If yes, which? Was(were) the symptom(s) presented before and/or after the act of violence?; (g) Did the victim engage in repetitive situations of violence (repetition compulsion)?

After registering the data observed on the forms, the data treatment considered the gross and relative frequencies of the performances and other movie characteristics relevant for the study objectives (quantitative analysis). After these calculations, these results were related to aspects focused on in the specialized literature on VAW, with emphasis on psychoanalytical literature, provided that this was feasible (qualitative analysis).

\section{Results and Discussion}

Concerning the movie genre, some movies revealed overlapping genres and each of these was considered independently $(N=24)$. This ranking was established based on the information collected from specialized websites on the theme (AdoroCinema, Cinepop etc.) and included: drama ( $n=17 ; 71 \%)$, thriller $(n=4$; $17 \%)$, action, biography and crime $(n=1 ; 4 \%$ each).

The permanence of the drama genre is related to the theme discussed, considering that the emotional aspects of the women who are victims of violence, as well as of the people who are direct or indirectly involved, can be understood or considered as truly dramatic, in the sense of what is touching in the performances. The movie Millennium: The girl with the dragon tattoo (Fincher, 2011) is an example of this aspect, as VAW was treated so emphatically that it aroused feelings like compassion, sadness and disgust in the public, demanding emotional conditions to cope with the information displayed, similar to Santeiro and Rossato's (2013) study of representations of childhood and adolescent sexual abuse in commercial movies.

As for the country of origin of the productions, nine (49\%) movies came from the United States, three $(16 \%)$ were Brazilian, two $(10 \%)$ were multinational co-productions, one was British, one Spanish, one French, one Greek and one Egyptian (5\% each). As a universal phenomenon that involves different cultures, independently of the level of economic development, VAW has been pictured in movies from several countries (Leal, 2010; Santos \& Vieira, 2011).

VAW was focused on as the core theme in $11(58 \%)$ movies and as a secondary theme in eight (42\%). In Arrêtez-moi (Lilienfeld, 2012), it was presented as the core theme; the movies 


\begin{tabular}{|c|c|c|c|}
\hline Title & Director, year of production & Genre & Country \\
\hline $678^{*}$ & Mohamed Diab, 2010 & Drama & Egypt \\
\hline An unfinished life & Lasse Hallström, 2005 & Drama & USA/Germany \\
\hline Antônia & Tata Amaral, 2006 & Drama & Brazil \\
\hline Arrêtez-moi* & Jean-Paul Lilienfeld, 2012 & Thriller & France \\
\hline Bordertown* & Gregory Nava, 2006 & Thriller/Drama & USA \\
\hline Elisa $K^{*}$ & Judith Colell, 2010 & Drama & Spain \\
\hline Kirot $^{*}$ & Danny Lerner, 2009 & Action/Drama & USA \\
\hline Lovelace & Rob Epstein \& Jeffrey Friedman, 2013 & Biography/Drama & USA \\
\hline Miss Violence* & Alexander Avranas, 2013 & Drama & Greece \\
\hline Mulheres do Brasil & Malu de Martino, 2006 & Drama & Brazil \\
\hline North Country* & Niki Caro, 2005 & Drama & USA \\
\hline Precious* & Lee Daniels, 2009 & Drama & USA \\
\hline Provoked* & Jag Mundhra, 2006 & Drama & $\begin{array}{l}\text { United Kingdom } \\
\text { India }\end{array}$ \\
\hline Safe haven* & Lasse Hallström, 2013 & Romance/Drama & USA \\
\hline Sonhos roubados & Sandra Werneck, 2009 & Drama & Brazil \\
\hline Straw dogs & Rod Lurie, 2011 & Thriller & USA \\
\hline $\begin{array}{c}\text { The Girl with the Dragon } \\
\text { Tattoo }\end{array}$ & David Fincher, 2011 & Drama/Thriller & USA \\
\hline Towelhead & Alan Ball, 2007 & Drama & USA \\
\hline Tyrannosaur* & Paddy Considine, 2011 & Drama & United Kingdom \\
\hline
\end{tabular}

Figure 1. List of titles in Brazilian Portuguese, director, year, genre and nationality of the production. Note. Asterisks after the title indicate works that have VAW as a core theme of their plots.

contain scenes that picture different types of violence (physical, sexual, psychological, equity and moral), and implications of the violent acts for the victim were displayed. One of these implications clearly shows the mental trauma Gaston (victim) experiences due to the violence, as well as the cycle of repetitive violent situations this character engages in (repetition compulsion). An unfinished life (Hallström, 2005) is an example of a movie in which VAW is discussed in the background, amidst the theme of starting over and the family conflicts the leading characters experience.

When the contexts the VAW occurred in were investigated, in the study sample, 26 epi- sodes of violence ${ }^{2}$ were found that took place in four contexts: in the family sphere $(n=15$; $58 \%)$, in public [streets, parks, squares etc.] ( $n=$ $6 ; 23 \%)$, at work $(n=4 ; 15 \%)$ and at school ( $n$ $=1 ; 4 \%)$. As the movie data demonstrate, VAW affects different groups and occurs in most of the contexts the women take part in. This modality of violence is one of the strongest expressions of patriarchy, which is supported and committed on a daily base by the media, school, religious institutions, family and the different existing

$2 \quad N$ increased because some movies pictured more than one episode. This phenomenon of an increasing sample will be repeated in other analyses. 
ideological appliances ${ }^{3}$ that reproduce this logic (Mesquita, 2010).

The family/home context was the most frequent in the violent scenes in the movies, representing $58 \%$ of the sample, similar to the findings in research not focused on movies undertaken by Mesquita (2010) and Madureira et al. (2014), who report that most violent episodes take place in the family context, which is the most private environment where the aggressors are most frequently located (partners, fathers, mothers and others), especially the partners. This reveals a perverse side of the family environment, historically constituted as a place of welcoming and safety, but which can turn into a space of conflict and violence (Mesquita, 2010).

When the age range of the women in situations of violence is analyzed, in 25 scenes, they were adults $(n=16 ; 64 \%)$, adolescents $(n=8$; $32 \%)$ and children $(n=1 ; 4 \%)$. Again, these data are similar to the findings in the research by Mesquita (2010) and also by Labronici, Ferraz, Trigueiro and Fegadoli (2010) and by Madureira et al. (2014), which indicated higher incidence levels of VAW in the adult phase.

In the movie Miss Violence (Avranas, 2013), the occurrence of VAW in childhood was observed, as the child is a victim of aggression together with the mother and adolescent sisters. It can be reaffirmed that the concept of VAW is broad and covers all phases of women's lifecycle, in accordance with the Brazilian National Policy for the Confrontation of Violence against Women (Politica Nacional de Enfrentamento à Violência contra as Mulheres, 2011). The recent nature of the historical movement of considering violence against children not as something "natural" and simply permitted as a consequence of aspects of "children's education", should also be highlighted in different cultures (the movie Miss Violence is a Greek production).

3 Ideological appliances are the different institutions responsible for establishing control over society, such as church, education, political, justice, among others; the action these appliances promote explains the presence of VAW in several contexts, as they permeate society as a whole.
In the sample, 25 scenes present the women's marital status in contexts of violence, as follows: married $(n=11,44 \%)$, single $(n=9$, $36 \%)$ and having a fixed partner $(n=5,20 \%)$. The literature reveals that most of the women are assaulted by their (former) partners. This type of observations reveals the mental and physical risks these women are exposed to as, in the majority of the cases, they are exposed to violence at home and the aggressor is a person they live with, whom they are emotionally involved with (Griebler \& Borges, 2013; Labronici et al., 2010; Lima \& Silva, 2012; Waiselfisz, 2015).

The analysis of the aggressors' age range reveals that, in 24 scenes, they were adults $(n=$ $22,92 \%)$ and adolescents $(n=2,8 \%)$. Data on the age range are in line with the investigated references, which appoint that most of the aggressors are in the adult phase of life (Griebler \& Borges, 2013; Madureira et al., 2014; Silva, Gomes, Acosta, Barlem, \& Fonseca, 2013). In the 24 scenes, the aggressors' marital status was as follows: married $(n=13,54 \%)$, single $(n=5$, $21 \%)$ and having a fixed partner $(n=6,25 \%)$, similar to the results by Madureira et al. (2014), found in non-movie contexts.

Concerning the relationship with the aggressor, the following data were found: absence of affective bonding ( $n=10,37 \%)$, wife $(n=7$, $26 \%$ ), girlfriend, former girlfriend and daughter $(n=3,11 \%$ each) and niece $(n=1,4 \%)$. When these data are related to the findings from the studies by Lima and Silva (2012), Mesquita (2010) and Silva et al. (2013), agreement is found in that most women in situations of violence are (former) wives and (former) girlfriends. Nevertheless, the highlight in the movies that, in $37 \%$ of the violence cases, the aggressors have no affective bond with the victims, goes against the findings demonstrated in other studies investigated (no movies). The study by Madureira et al. (2014) is an example that reveals this contradiction. One example of a movie in which aggressors without any type of affective bond with the victims commit the violence is 678 (Diab, 2010), an Egyptian production about the aggressions women are victims of in different public environments, committed by unknown people. This 
raises a discussion on women's difficulties to denounce and admit that they are victims of violence in Egypt (country of origin of the movie).

As regards the types of violence committed against women, 72 episodes were found, subdivided in the following categories: psychological $(n=19,26 \%)$, physical $(n=18,25 \%)$, sexual $(n$ $=16,22 \%)$, moral $(n=12,17 \%)$ and equity $(n$ $=7,10 \%)$. Although the types were separated for analysis purposes, the titles analyzed always reveal combinations. In some movies, all types of violence appeared, like in the case of Precious (Daniels, 2009), when the leading character, a 16-year-old girl, is a victim of sexual violence committed by her father and psychological, moral, physical and equity violence by her mother.

Studies like Griebler and Borges (2013), Labronici et al. (2010), Lima and Silva (2012) and Madureira et al. (2014), appoint, as observed in the movies, the higher incidence levels of psychological and physical violence, although not rarely accompanied by the other types. The family psychodynamics of the movie by Daniels (2009) was the focus of a study by Santeiro, Rossato, Juiz and Gobbetti (2014).

Considering the strong impact violence causes in the women's life, overcoming this condition involves different social segments, demanding various perspectives and intervention modalities, including the clinical psychologist (Conselho Federal de Psicologia, 2011). Concerning psychological care to women in situations of violence, the psychologist needs both a theoretical-clinical and social background. As care for this segment does not normally happen in traditional clinical settings, the concept of the expanded clinic needs to be considered, which leads to the expansion of the clinical psychologist's different activity forms, adapting clinical practice to the different spaces it is needed in (Monteiro, 2012). Thus, the psychologist can expand the range of clinical work with women in situations of violence, as this type of model considers partnerships with other sectors, such as Justice, public safety and social services.

Alluding to the implications the act of violence can cause for women, 46 scenes were observed that were classified as follows: mental traumatization ( $n=17,37 \%)$, distancing from family/friends and low self-esteem ( $n=7,15 \%$ each), departure/abandonment of home $(n=6$, $13 \%)$, loss of employment ( $n=3,7 \%)$, pregnancy and death ( $n=2,4 \%$ each) and end of the relationship and suicide ( $n=1,2 \%$ each). The repercussion and the implications of violence can be felt in physical and mental health, as well as in the social field the woman is inserted in, in an inseparable manner (Madureira et al., 2014; Paiva, Santos, \& Santos, 2014). They are discussed separately for didactical reasons only.

As an example of a physical implication of the act of violence, Precious (Daniels, 2009) can be highlighted, in which the leading character has two unwanted pregnancies and catches $\mathrm{HIV}$, as consequences of the violence suffered. Arrêtez-moi (Lilienfeld, 2012) gives examples of implications for the woman's mental health; in the movie, after being assaulted, the leading character develops a panic syndrome that makes it impossible for her to lead a common life. In North country (Caro, 2005) a model of violence is observed that causes implications in the social sphere of women's life, that is, losing one's job and distancing from the family and friends.

To understand what happens physical and emotionally to women victims of violence, the subject needs to be focused on, the human being whose entire life the violence affected (Paiva et al., 2014). The clinical psychologist can offer this specialized look, who in this context can take part in the coping process with the violence cycle, in the attempt to prevent it, treat it and promote health.

Specifically considering mental traumatization, in $17(85 \%)$ movies, the women in situations of violence presented a symptom or a set of symptoms after the violent act itself. It should be considered that the mental trauma duels with attempts towards elaboration and psychic inscription, when the pain and anguish reach such an intolerable level that the feeling of rupture of the I will emerge in the person, accompanied by several other symptoms (Freud, 1920/1996). The act of violence represents a landmark here in these women's life, starting from which signs of traumatization will emerge, because it represents 
the trauma itself.

The analysis of the violence victims' symptoms revealed 37 scenes. They were classified as: post-traumatic stress $(n=15,41 \%)$, anxiety ( $n=7,20 \%)$, depression, delusions and hallucinations $(n=5,13 \%$ each). As mentioned earlier, Freud (1920/1996) described the trauma as a pain that cannot be psychically represented and this lack of representation entails a great impact in the human subjectivation process.

The trauma pictures a pain that cannot be represented and it is hardly admirable that such pain caused the development of conflicts and psychological symptoms, like those found in the characters from the movies studied. In the movies, the symptoms did not appear isolated from one another and the woman experiencing violence presented more than one of the symptoms raised, as shown in movies like: Precious (Daniels, 2009), Arrêtez-moi (Lilienfeld, 2012), Elisa K. (Colell, 2010) and Provoked (Mundhra, 2006).

Concerning the repetition compulsion, in 11 $(58 \%)$ works, the characters in violent situations put themselves in repetitive conditions of violence, as opposed to the remaining eight (42\%). It should be reminded that the repetition compulsion mechanism emerges based on the effect of the trauma, in a complex psychic dynamics, where the afflictive and disturbing events "return", configuring certain subjects' action to rethink distressing facts in their lives, without acknowledging their own role in causing these incidents or in relating them with past situations (Paim, 2010).

One specific issue in the repetition compulsion is the fact of reaffirming, in different ways, the anguishing fact in question, but this happens without any awareness of repeating similar content (Freud, 1920/1996). Arrêtez-moi (Lilienfeld, 2012) illustrates the relationship prototype in which the repetition compulsion mechanism appears. Gaston - the leading character - narrates her story, in which a family history of violence appears. The father used to assault the mother and she witnessed these conflicts in her child past. In her current relationships, Gaston relives these situations of intrafamily violence.
Thus, she follows roads similar to difficulties her mother experienced, in accordance with Barbosa (2010).

This shows that the women in the movies analyzed engage in repetitive situations of violence also because of their past history of violence. Starting from this history, they seem to unconsciously tend to repeat trajectories that are somehow "familiar", as if they asked themselves: "my mother was like that, mistreated by my father, so that's how I'll be in my relationships with men". That is, the composition of their internal family would be permeated by violence as a possible language.

The movies in which the women did not present the repetition compulsion mechanism were the same in which the violence theme was focused on peripherally, like for example: An unfinished life (Hallström, 2005), Antônia (Amaral, 2006) and Straw dogs (Lurie, 2011). Thus, this characteristic leads to the finding that, because it is not the movies' main theme and, therefore, because there is no diversity and depth in the scenes, this type of aspect could not be observed in the respective characters' histories.

\section{Final Considerations}

The movies studied present scenes on the themes and characteristics of the people involved in situations of VAW, similar to those focused on in the specialized literature concerning contexts, profiles of the women in situations of violence and the occurrence of psychic traumatization. Thus, they permit further approaches between the realities in the movies and the facts.

This approach between the movies and reality is not intended to replace the study of theories and even less to exactly transpose one type of experience to the other, but to serve as yet another tool in the education process of clinical psychologists. Thus, through this study, we intended to highlight the movies' language as a trigger of discussions and a provoker of knowledge beyond the knowledge that can be obtained rationally, in the academy.

Hence, it can be considered that the movies focused on the theme VAW here can serve 
as tools in this education process, confronting the Psychology student with situations similar to what the students will meet in "real" work environments, as well as with experiences of nuances in the feelings these humans situations can provoke. In this context, the clinical psychologist needs to be emotionally available, characterized by the ability to develop and exercise empathy, as the women in situations of violence cannot be left at the mercy of another type of violence when they are heard: the indifference towards their reported suffering.

The professionals active in this area are responsible for helping to rescue the women's autonomy, often lost by the traumatizing experiences. After all, it should be reminded that coping with VAW should comprise the dimensions of prevention, care and the guarantee of women's rights (Politica Nacional de Enfrentamento à Violência contra as Mulheres, 2011). As a complement to the care that needs to be provided to women in situations of violence, it should also be highlighted that, nowadays, the activities the clinical psychologist and other professionals involved in situations of coping with VAW should include the aggressor in their care focus. Understanding VAW as a complex, historically constituted and multicausal phenomenon should be considered seriously, even when one intends to study its manifestations in movies.

The existence of other movies on VAW the search did not select is considered a methodological limitation. Nevertheless, based on the movies considered here, several of its aspects could be understood and some implications for education processes of clinical psychologists can be highlighted for anyone interested in the theme.

Another limitation derives from the focus on the data treatment. The corresponding analyses were intended to understand the movies as a whole, making it possible to discuss and theoretically support highly complex themes only briefly. This type of restriction can be overcome by, selecting, in future studies, a title as a case study, in line with contributions like Pinheiro (2012) and Santeiro et al. (2014).

In short, Cinema can be used as a tool to illustrate VAW to psychology students by pic- turing situations corresponding to the situations they will face in the reality of their work, even if through artistic language. It can serve as an introduction to the study of polemic themes that are hard to approach, as well as to trivial themes in the teaching-learning process, turning into an additional resource in the education process of clinical psychologists (Santeiro, 2013). In that sense, it can be a meaningful didactic tool that encourages and expands debates on gender and health promotion issues in the study area of VAW.

\section{References}

Amaral, T. (Dir.). (2006). Antônia [Motion picture]. Brazil. Cor. 90 min.

Avranas, A. (Dir.). (2013). Miss Violence [Motion picture]. Grécia. Cor. 98 min. Legendado.

Ball, A. (Dir.). (2007). Towelhead/Tabu [Motion picture]. Estados Unidos. Cor. $124 \mathrm{~min}$. Legendado.

Barbosa, E., Neto. (2010). O conceito de repetição na psicanálise freudiana: Ressonâncias clínicas na reelaboração simbólica do repetido (Dissertação de mestrado em Psicologia Clínica, Universidade Católica de Pernambuco, Recife, PE, Brazil). Retrieved from http://www.unicap.br/ tede//tde_busca/arquivo.php? codArquivo $=302$

Bernardet, J. C. (2006). O que é cinema. São Paulo, SP: Brasiliense.

Caro, N. (Dir.). (2005). North Country/ Terra fria [Motion picture]. Estados Unidos. Cor. 126 min. Legendado.

Colell, J. (Dir.). (2010). Elisa $K$ [Motion picture]. Espanha. Cor. $71 \mathrm{~min}$. Legendado.

Considine, P. (Dir.). (2011). Tyrannosaur/Tiranossauro [Motion picture]. Reino Unido. Cor. 92 min. Legendado.

Conselho Federal de Psicologia. (2011). Documento de referência para atuação dos psicólogos em serviços de atenção a mulher em situação de violência. Retrieved from http://www.crprj.org. br/documentos/2012-doc_mulheres.pdf

Daniels, L. (Dir.). (2009). Precious/Preciosa: Uma história de esperança [Motion picture]. Estados Unidos. Cor. 110 min. Legendado. 
Decreto-lei N. ${ }^{\circ} 11.340$, de 7 de agosto de 2006. (2006). Cria mecanismos para coibir a violência doméstica e familiar contra a mulher. Brasília, DF: Presidência da República, Casa Civil, Subchefia para Assuntos Jurídicos. Retrieved from http://www.planalto.gov.br/ccivil_03/_ato20042006/2006/lei/111340.htm

Diab, M. (Dir.). (2010). 678/Cairo 678 [Motion picture]. Egito. Cor. 100 min. Legendado.

Edgard-Hunt, R., Marland, J., \& Rawle, S. (2013). A linguagem do Cinema. Porto Alegre, RS: Bookman.

Epstein, R. (Dir.), \& Friedman, J. (Dir.). (2013). Lovelace [Motion picture]. Estados Unidos. Cor. 93 min. Legendado.

Fincher, D. (Dir.). (2011). The girl with the dragon tattoo/Milllenium: Os homens que não amavam as mulheres [Motion picture]. Estados Unidos. Cor. 158 min. Legendado.

Fiorini, L. G. (2008). Los laberintos de la violência. Buenos Aires: Asociación Psicoanalítica Argentina.

Freud, S. (1996). Além do princípio de prazer. In S. Freud, Edição standard brasileira das obras psicológicas completas de Sigmund Freud (Vol. 18, pp.11-75). Rio de Janeiro, RJ: Imago. (Original publicado em 1920)

Griebler, C. N., \& Borges, J. L. (2013). Violência contra a mulher: Perfil dos envolvidos em boletins de ocorrência da Lei Maria da Penha. Psico, 44(2), 215-225. Retrieved from http://revistaseletronicas.pucrs.br/ojs/index.php/revistapsico/ article/view/11463/9640

Hallström, L. (Dir.). (2005). An unfinshed livel Um Lugar para Recomeçar [Motion picture]. Estados Unidos; Alemanha. Cor. $101 \mathrm{~min}$. Legendado.

Hallström, L. (Dir.). (2013). Safe Haven/Um porto seguro [Motion picture]. Estados Unidos. Cor. 116 min. Legendado.

Hanada, H., D’Oliveira, A. F. P. L., \& Schraiber, L. B (2011). Os psicólogos na rede de assistência a mulheres em situação de violência. Estudos $\mathrm{Fe}$ ministas, 18(1), 33-59.

Labronici, L. M., Ferraz, M. I. R., Trigueiro, T. H., \& Fegadoli, D. (2010). Perfil da violência contra mulheres atendidas na Pousada de Maria. Revista da Escola de Enfermagem da USP, 44(1), 126133. doi:10.1590/S0080-62342010000100018
Leal, S. M. C. (2010). Lugares de (não) ver - As representações sociais da violência contra a mulher na Atenção Básica de Saúde (Tese de doutorado em Enfermagem, Universidade Federal do Rio Grande do Sul, Porto Alegre, RS, Brazil). Retrieved from http://www.lume.ufrgs. br/bitstream/handle/10183/28043/000768933. pdf? sequence $=1$

Lerner, D. (Dir.). (2009). Kirot (The assassin next door)/Lado a lado com um assassino [Motion picture]. Israel. Cor. 103 min. Legendado.

Lilienfeld, J. P. (Dir.). (2012). Arretez moi/Prendame [Motion picture]. França. Cor. $99 \mathrm{~min}$. Legendado.

Lima, V. L., \& Silva, A. F. (2012). Conhecendo o perfil e os sentimentos das mulheres vítimas de violência atendidas na Delegacia Especializada de Atendimento à Mulher do município de Belém. Gênero na Amazônia, 2, 111-123. Retrieved from http://www.generonaamazonia.ufpa.br/ edicoes/edicao-2/Artigos/Conhecendo $\% 20$ o\%20Perfil\%20e\%20os\%20Sentimentos $\% 20$ de $\% 20$ Mulheres $\% 20 \mathrm{~V} \% \mathrm{C} 3 \%$ ADtimas $\% 20$ de $\% 20$ Viol $\%$ C3\%AAncia $\% 20$ Atendidas $\% 20$ na $\% 20$ Delegacia $\% 20$ Especializada $\% 20 \mathrm{de} \% 20$ Atendimento $\% 20 \% \mathrm{C} 3 \% \mathrm{~A} 0 \% 20 \mathrm{Mulher} \% 20$ do $\% 20 \mathrm{Munic} \% \mathrm{C} 3 \%$ ADpio $\% 20$ de $\% 20$ Bel\%C3\%A9m.pdf

Lima, G. Q., \& Werlang, B. S. G. (2011). Mulheres que sofrem violência doméstica: Contribuições da psicanálise. Psicologia em Estudo, 16(4), 511520. doi:10.1590/S1413-73722011000400002

Lurie, R. (Dir.). (2011). Strow Dogs/Sob o domínio do medo [Motion picture]. Estados Unidos. Cor. $110 \mathrm{~min}$. Legendado.

Madureira, A. B., Raimondo, M. L., Ferraz, M. I. R., Marcovicz, G. V., Labronici, L. M., \& Mantovani, M. F. (2014). Perfil de homens autores de violência contra mulheres detidos em flagrante: Contribuições para o enfrentamento. Escola Anna Nery Revista de Enfermagem, 18(4), 600606. doi:10.5935/1414-8145.20140085

Martino, M. (Dir.). (2006). Mulheres do Brasil [Motion picture]. Brazil. Cor. $106 \mathrm{~min}$.

Mesquita, A. P. (2010). As Marias que não calam: Perfil das mulheres vitimas de violência após a implementação da lei Maria da Penha em Maceió/AL. Retrieved from http://www.fazendogenero.ufsc.br/9/resources/anais/1278269236 ARQUIVO_Texto_Competo_asmariasFG9.pdf 
Monteiro, F. S. (2012). O papel do psicólogo no atendimento às vítimas e autores de violência doméstica. Brasília, DF. Retrieved from http://repositorio.uniceub.br/bitstream/123456789/2593/3/20820746.pdf

Moreira, J. O., Romagnoli, R. C., \& Neves, E. O. (2007). O surgimento da clínica psicológica: Da prática curativa aos dispositivos de promoção da saúde. Psicologia: Ciência e Profissão, 27(4), 608-621. doi:10.1590/S141498932007000400004

Mundhra, J. (Dir.). (2006). Provoked/Desejo de liberdade [Motion picture]. Reino Unido, Índia. Cor. 113 min. Legendado.

Nava, G. (Dir.). (2006). Bordertown/Cidade do silêncio [Motion picture]. Estados Unidos. Cor. 100 min. Legendado.

Paim, I. A., Filho. (2010). Compulsão à repetição: Pulsão de morte "trans-in-vestida" de libido. Revista Brasileira de Psicanálise, 44(3), $117-$ 126. Retrieved from http://pepsic.bvsalud.org/ scielo.php?script $=$ sci_arttext\&pid $=$ S0486$-641 \mathrm{X} 2010000300012$

Paiva, A. C. R., Santos, V. R. P., \& Santos, S. M. (2014). Violência doméstica e as implicações na saúde física e emocional de mulheres: Inferências de enfermagem. Paper presented at the SEGET: XI Simpósio de Excelência em Gestão e Tecnologia. Retrieved from http://www.aedb. br/seget/arquivos/artigos14/23020192.pdf

Pinheiro, R. K. (2012). O cinema e a violência contra mulher. $O$ discurso de autoria femininal masculina em três produções Hollywoodianas. Retrieved from http:/www.abrapui.org/anais/ ComunicacoesCoordenadasLingua/22.pdf

Pimentel, A. (2011). Violência psicológica nas relações conjugais: Pesquisa e intervenção clínica. São Paulo, SP: Summus.

Política Nacional de Enfrentamento à Violência contra as Mulheres. (2011). Brasília, DF: Presidência da República, Secretaria de Políticas para as Mulheres. Retrieved from http://www.spm.gov. br/sobre/publicacoes/publicacoes/2011/politicanacional

Portella, M., Cortez, M., \& Carpigiani, P. (2011). Os primeiros passos do psicoterapeuta. In B. Carpigiani (Ed.), Teorias e técnicas de atendimento em consultório de Psicologia (pp. 269-281). São Paulo, SP: Vetor.
Santeiro, T. V. (2013). Cinema e realidades na formação em Psicologia Clínica: Proposições teóricas. In T. V. Santeiro \& D. R. Barbosa (Eds.), $A$ vida não é filme? Reflexões sobre Psicologia e Cine$m a$ (pp. 175-202). Uberlândia, MG: Editora da Universidade Federal de Uberlândia.

Santeiro, T. V., \& Rossato, L. (2013). Cinema e abuso sexual na infância e adolescência: Contribuições à formação do psicólogo clínico. Psicologia: Teoria e Prática, 15(3), 83-94. Retrieved from http://pepsic.bvsalud.org/scielo.php?script $=$ sci arttext\&pid $=$ S1516-36872013000300006\&lng= pt\&nrm $=$ iso

Santeiro, T. V., Rossato, L., Juiz, A. P. M., \& Gobbetti, G. J. (2014). Psicodinâmica das relações incestuosas: Assassinato e renascimento da alma em Preciosa. Psicologia em Estudo, 19(1), 93102. doi:10.1590/1413-7372189590009

Santos, M. A., \& Vieira, E. M. (2011). Recursos sociais para apoio as mulheres em situação de violência em Ribeirão Preto, SP, na perspectiva de informantes-chave. Interface Comunicação Saúde Educação, 15(36), 93-108. doi:10.1590/ S1414-32832011000100008

Silva, C. D., Gomes, V. L. O., Acosta, D. F., Barlem, E. L. D., \& Fonseca, A. D. (2013). Epidemiologia da violência contra a mulher: Características do agressor e do ato violento. Revista de Enfermagem da UFPE online, 7(1), 8-14. doi:10.5205/ reuol.3049-24704-1-LE.0701201302

Strasburger, V. C., Wilson, B. J., \& Jordan, A. B. (2011). Crianças, adolescentes e a mídia (2 ${ }^{\text {nd }}$ ed.). Porto Alegre, RS: Penso.

Vieira, M. A. (2013). A violência do trauma e seu sujeito. In O. M. R. Machado \& E. Derezensky (Eds.), A violência: Sintoma social da época (pp.73-89). Belo Horizonte, MG: Scriptum Livros.

Waiselfisz, J. J. (2015). Mapa da violência 2015: A cor dos homicídios no Brasil. Rio de Janeiro, RJ: Flacso.

Werneck, S. (Dir.). (2009). Sonhos roubados [Motion picture]. Brazil. Cor. 85 min. 